\title{
SPATIAL VARIABILITY OF RESISTANCE TO PENETRATION IN SOIL UNDER SUGARCANE CROPS WITH DIFFERENT HARVEST METHODS ${ }^{1}$
}

\author{
MAIRA DA CUNHA SOUZA ${ }^{2}$, FLAVIO PEREIRA DE OLIVEIRA ${ }^{2 *}$, JOSÉVALDO RIBEIRO SILVA $^{3}$, ADRIANA \\ FERREIRA MARTINS ${ }^{2}$, PEDRO LUAN FERREIRA DA SILVA ${ }^{4}$
}

\begin{abstract}
The objective of this work was to evaluate the spatial variability of resistance to penetration in soil under sugarcane crops subjected to different harvest methods in the North Coast microregion of the state of Paraiba, Brazil. The study was conducted in a Typic Hapludult under sugarcane crops, at the farms Santa Emília-II and Maria da Luz-I of the company Miriri Food and Bioenergy S/A, in the municipalities of Rio Tinto and Capim, respectively, state of Paraíba, Brazil. Three sugarcane areas with different harvest methods (manual, mechanized, and manual/mechanized) were selected. The sampling was done in plots of $100 \times 100 \mathrm{~m}$, using a grid of $20 \times 20 \mathrm{~m}$, covering planting rows and interrows; each intersection point of the grid was georeferenced, and the soil mechanic resistance to penetration was evaluated with the aid of an impact penetrometer (IAA/Planalsucar-Stolf) up to the depth of 0-0.6 m. Soil disturbed and undisturbed samples from the 0.0-0.1 and 0.1-0.2 m layers were collected for analyses of soil moisture, texture, clay dispersed in water, flocculation degree. A pure nugget effect was found in the 0.0-0.1 and 0.4-0.5 m soil layers in the rows of the areas with manual/mechanized harvest. The spherical model was found for most conditions evaluated. The results for the areas were similar, with amplitude of 25-49 m, indicating that the harvest management had no effect on the soil resistance to penetration. No compacted areas were found, and the spatial dependency of the resistance to penetration was characterized as moderate to strong.
\end{abstract}

Keywords: Soil compaction. Controlled traffic. Geostatistics.

\section{VARIABILIDADE ESPACIAL DA RESISTÊNCIA A PENETRAÇÃO EM SOLO SOB DIFERENTES CONDIÇÕES DE COLHEITA DE CANA-DE-AÇÚCAR}

RESUMO - O objetivo deste trabalho foi avaliar a variabilidade espacial da resistência a penetração em solo sob diferentes condições de colheita de cana-de-açúcar na microrregião do Litoral Norte paraibano. O estudo foi realizado em Argissolo Acinzentado cultivado com cana-de-açúcar, nas fazendas Santa Emília II e Maria da Luz I, pertencentes à Usina Miriri e Bioenergia S/A, nos municípios de Rio Tinto e Capim, estado da Paraíba no Brasil. Selecionou-se três áreas: Colheita manual; Colheita mecanizada e; Colheita manual e mecanizada. As coletas se procederam em parcelas de $100 \times 100 \mathrm{~m}$, sob grid de amostragem de $20 \times 20 \mathrm{~m}$, contemplando linhas e entrelinhas de plantio, sendo cada ponto de cruzamento da malha amostral georreferenciado, e levantada a sua resistência mecânica à penetração com auxílio de um penetrômetro de impacto modelo IAA/ Planausucar-Stolf na profundidade de 0-0,6 m. Foi procedida coleta de amostra deformadas e indeformadas nas profundidade de 0-0,1 e 0,1-0,2 m para análises das seguintes variáveis: Umidade do solo, Textura, Argila dispersa em água, Grau de floculação. Observou-se efeito pepita puro nas camadas de 0-0,1 e 0,4-0,5 m na linha da área de colheita manual e mecanizada. $\mathrm{Na}$ maioria das condições analisadas constatou-se o modelo esférico. Os alcances foram semelhantes para áreas, com amplitude de 25 a $49 \mathrm{~m}$, indicando que o manejo de colheita, no período estudado, não exerceu influência para a resistência à penetração. Não foram observadas áreas compactadas e a dependência espacial da resistência à penetração foi caracterizada como moderada a forte.

Palavras-chave: Compactação do solo. Tráfego controlado. Geoestatística.

\footnotetext{
"Corresponding author

${ }^{1}$ Received for publication in $06 / 12 / 2019$; accepted in 03/09/2020.

Paper extracted from the master dissertation of the first author.

${ }^{2}$ Department of Soils and Rural Engineering, Universidade Federal da Paraíba, Areia, PB, Brazil; mairasouza10@hotmail.com - ORCID: 0000-0002-8498-155X, pereira@cca.ufpb.br - ORCID: 0000-0001-7968-6145, biol.adriana@gmail.com - ORCID: 0000-0002-8960-3101.

${ }^{3}$ Department of Agronomy, Universidade Federal Rural de Pernambuco, Recife, PE, Brazil; valdo_rb@hotmail.com - ORCID: 0000-00015594-5624.

${ }^{4}$ Department of Agronomy, Universidade Estadual de Maringá, Maringá, PR, Brazil; pedroluanferreira@gmail.com - ORCID: 0000-00015520-7920.
} 


\section{INTRODUCTION}

Sugarcane is an important crop for the economy of many countries, and is a source of food and bioenergy. Brazil is the largest sugarcane producing country, with approximately $39 \%$ of world's production, followed by India, Thailand, and Pakistan (FAO, 2014).

According to the Brazilian National Food Supply Company (CONAB), the state of Paraíba is the third largest sugarcane producing state in the last ten years in the Northeast region, after Pernambuco and Alagoas, with aplanted area of 110,300 hectares and a production of $4,856,100 \mathrm{Mg}$ in the $2016 / 2017$ crop season (CONAB, 2017).

In the 1990's, the Brazilian sugar-energy sector focused on increasing technologies for a greater competitiveness in the market, implementing the use of mechanized harvesters for sugarcane crops; moreover, soil management in sugarcane crops is one of the most aggressive practices, considering the large number of machinery operations throughout the crop stages (CASTRO et al., 2013).

The sugarcane mechanized harvest system requires the use of load-transfers and harvesters with total weights of $20-30 \mathrm{Mg}$, whose frequent traffic during several crop cycles and under several soil hydrological conditions results in soil physical changes, mainly in increasing soil compaction, which decreases crop yield (BRAUNACK et al., 2006).

Understanding and measuring the effects of soil use and management are essential for the development of sustainable agricultural systems to conserve and improve soil quality, avoiding soil degradation and increasing crop yield. The development of sugarcane crops increases the concern on problems of soil compaction resulted from the intense heavy machinery traffic (SILVA; CABEDA, 2006).

Considering the heterogeneity of soils, monitoring and analysis of the soil physical quality over the crop stages are strategies for conducting management systems focused on the mitigation of structural soil degradation (CAVALIERI et al., 2011). Geostatistics is a tool indicated for the study of soil attributes that vary in the space, which enables the development of information and maps that evidence the distribution of these attributes in the field, providing subsidies for an adequate soil management (SOUZA et al., 2009).

Therefore, the objective of this work was to evaluate the spatial variability of resistance to penetration in soil under sugarcane crops subjected to different harvest methods in the North Coast microregion of the state of Paraiba, Brazil.

\section{MATERIAL AND METHODS}

The study was conducted in three sugarcane producing areas of the Miriri Food and Bioenergy S/ A, two of them in in the Santa Emília-II farm, in the municipality of Rio Tinto, and one in the Maria da Luz-I farm, in the municipality of Capim, state of Paraíba, Brazil (Figure 1). These municipalities are in the Zona da Mata region, whose climate is As', tropical rainy with dry summer, according to the Köppen classification, presenting mean annual rainfall depth of $1,600 \mathrm{~mm}^{\text {year }}{ }^{-1}$ and mean annual temperature of $26^{\circ} \mathrm{C}$.
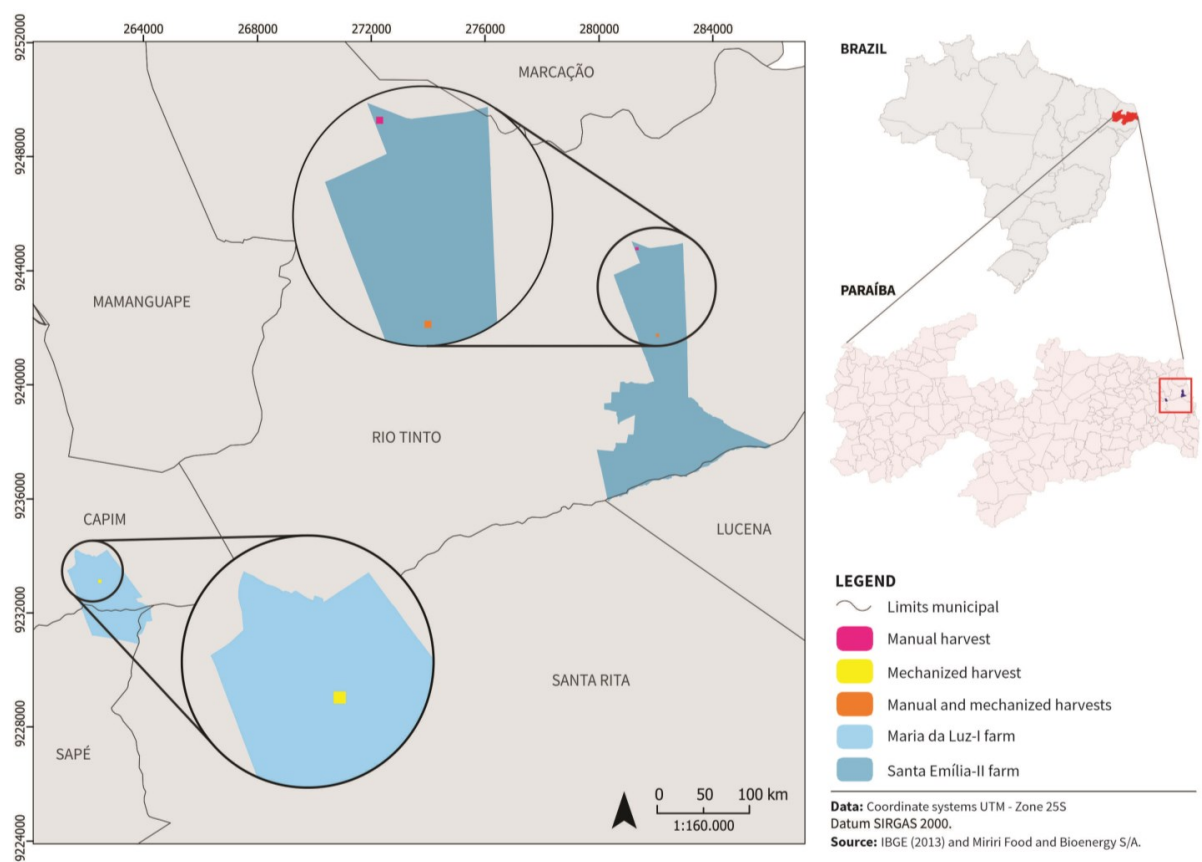

Figure 1. Location of the sampling areas in the Maria da Luz-I farm and Santa Emília-II farm, in the municipalities of Capim and Rio Tinto, respectively, state of Paraíba, Brazil. 
The soil of the three areas was classified as Typic Hapludult (Argissolo Acinzentado; SANTOS et al., 2018). The areas had been subjected to two manual harvest (MAH) $\left(6^{\circ} 49^{\prime} 42.36 " \mathrm{~S}, \quad 34^{\circ}\right.$ $\left.58^{\prime} 43.48^{\prime \prime} \mathrm{W}\right)$; two mechanized harvest $(\mathrm{MEH})\left(6^{\circ}\right.$ $\left.55^{\prime} 59.29^{\prime \prime} \mathrm{S}, 35^{\circ} 8^{\prime} 59.30^{\prime \prime} \mathrm{W}\right)$; or manual/mechanized harvest (two manual and two mechanized harvests) (MMH) (651'21.39"S, 3458'20.39"W) (Figure 1).

The sampled areas are part of a commercial sugarcane crop, which were systematized in double rows for mechanized harvest with spacing of $0.80 \mathrm{~m}$ between rows and $1.60 \mathrm{~m}$ between interrows. The areas were determined with a GNSS receptor (GPSMAP ${ }^{\circledR} 76 \mathrm{CSx}$; Garmin), using the Sirgas 2000 Datum, Zone 25 South. The samples were collected using a regular grid spacing $20 \times 20 \mathrm{~m}$ in plots of $100 \times 100 \mathrm{~m}(1 \mathrm{ha})$. Trenches were opened in the center of each plot and soil samples were collected in every $0.10 \mathrm{~m}$ layer up to $0.60 \mathrm{~m}$ to determine soil moisture. Each intersection point of the grid was georeferenced and the soil resistance to penetration
(SRP) was determined in the planting row and interrow, totaling 50 sampling points per area.

The soil granulometry was assessed through the Bouyoucos densimeter method (GEE; BAUDER, 1986), using sodium hydroxide ( $\left.\mathrm{NaOH} 1 \mathrm{~mol} \mathrm{~L}^{-1}\right)$ as chemical dispersant, and mechanical agitation as physical dispersant (Table 1). The clay dispersed in water was evaluated using the same procedure used for the granulometry analysis, but without the use of chemical dispersant (TEIXEIRA et al., 2017). The total and water dispersed clay data were used to calculate the soil flocculation degree (Equation 1):

$$
D f=\left[\left(\frac{\text { Clay }- \text { Clay }_{\mathrm{H}_{2} \mathrm{O}}}{\text { Clay }}\right) \times 100\right]
$$

where $D f$ is the degree of flocculation (\%), Clay is the clay dispersion in $\mathrm{NaOH}\left(\mathrm{g} \mathrm{kg}^{-1}\right)$, and Clay $_{\mathrm{H}_{2} \mathrm{O}}$ is the clay dispersion in water $\left(\mathrm{g} \mathrm{kg}^{-1}\right)$.

Table 1. Soil granulometry, clay dispersed in water (CDW), soil textural classification and flocculation degree for sugarcane areas under manual, mechanized, and manual/mechanized harvests.

\begin{tabular}{|c|c|c|c|c|c|c|}
\hline \multirow{2}{*}{ Soil layer (m) } & \multicolumn{3}{|c|}{ Soil granulometry } & \multirow{2}{*}{ CDW } & \multirow{2}{*}{ Textural Class } & \multirow{2}{*}{$\begin{array}{c}\text { Flocculation } \\
\text { degree }\end{array}$} \\
\hline & Sand & Silt & Clay & & & \\
\hline \multicolumn{6}{|c|}{ 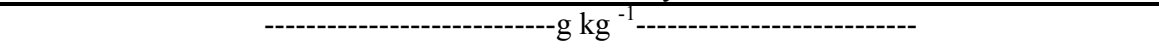 } & $\%$ \\
\hline \multicolumn{7}{|c|}{$\begin{array}{c}\text { Manual harvest } \\
\text { Planting row }\end{array}$} \\
\hline $0.0-0.1$ & 884 & 55 & 61 & 0 & Loamy Sand & 100 \\
\hline $0.1-0.2$ & 878 & 51 & 71 & 0 & Loamy Sand & 100 \\
\hline \multicolumn{7}{|c|}{ Planting interrow } \\
\hline $0.0-0.1$ & 896 & 57 & 47 & 0 & Sand & 100 \\
\hline $0.1-0.2$ & 899 & 49 & 52 & 8 & Sand & 84.6 \\
\hline & & & echaniz & est & --- & . \\
\hline \multicolumn{7}{|c|}{ Planting row } \\
\hline $0.0-0.1$ & 865 & 44 & 91 & 0 & Loamy Sand & 100 \\
\hline $0.1-0.2$ & 847 & 40 & 113 & 0 & Loamy Sand & 100 \\
\hline \multicolumn{7}{|c|}{ Planting interrow } \\
\hline $0.0-0.1$ & 864 & 59 & 77 & 0 & Loamy Sand & 100 \\
\hline $0.1-0.2$ & 864 & 43 & -93 & -5 & _Loamy Sand . & -94.6 \\
\hline & & & $1 / \mathrm{mech}$ & arve & & \\
\hline \multicolumn{7}{|c|}{ Planting row } \\
\hline $0.0-0.1$ & 899 & 32 & 68 & 0 & Sand & 100 \\
\hline $0.1-0.2$ & 888 & 25 & 87 & 0 & Loamy Sand & 100 \\
\hline \multicolumn{7}{|c|}{ Planting interrow } \\
\hline $0.0-0.1$ & 901 & 32 & 67 & 0 & Sand & 100 \\
\hline $0.1-0.2$ & 903 & 32 & 65 & 0 & Sand & 100 \\
\hline
\end{tabular}

The soil resistance to penetration was determined in each sample point up to $0.60 \mathrm{~m}$ depth, with the aid of an impact penetrometer (IAA/ Planalsucar-Stolf). The number of impacts was counted, and the penetration depth reached by the rod into the soil layers was recorded and converted to MPa units, according to (Equation 2):

$$
S R P=\left[\frac{M g+m g+\left(\frac{M}{M+m} \times \frac{M g \times h}{X}\right)}{A}\right] \times 0.098
$$

where $S R P$ is the soil resistance to penetration, $M$ is 
the weight of the piston $(4.03 \mathrm{~kg}), \mathrm{g}$ is the gravity acceleration $\left(9.8 \mathrm{~m} \mathrm{~s}^{-2}\right), m$ is the weight of the device without the piston $(3.24 \mathrm{~kg}), h$ is the height ran by the piston $(0.56 \mathrm{~m}), x$ is the penetration of the rod into the soil (cm per impact), and $A$ is the basal area of the $\operatorname{rod}\left(\mathrm{m}^{2}\right)$.

The dataset of soil resistance to penetration was characterized and summarized through descriptive statistics before the geostatistical analysis, by calculating the maximum value, minimum value, mean, median, standard deviation, coefficient of variation, coefficient of asymmetry, and kurtosis value. The coefficient of variation (CV) was evaluated according to Warrick and Nielsen (1980), classifying as low $(<12 \%)$, moderate $(12 \%$ to $60 \%)$, and high $(>60 \%)$.

The geostatistical analysis was done in two phases, using the Surfer ${ }^{\circledR} 13$ program. The first phase was done through empirical semivariograms, evaluating the spatial dependency of the variable in each layer of the plantin grow and planting interrow. The semivariograms were estimated by the intrinsic hypothesis theory, which assumest hat measurements separated by small distances are more similar to each other than those separated by longer distances (OLIVEIRA et al., 2013). The semivariance was obtained using (Equation 3):

$$
\hat{\gamma}(h)=\frac{1}{2 N(h)} \sum_{i=1}^{N(h)}\left[Z\left(x_{i}\right)-Z\left(x_{i}+h\right)\right]^{2}
$$

where $\hat{\gamma}(h)$ is the semivariance value for the distance $h ; N(h)$ is the number of pairs involved with the calculation of semivariance; $Z(x i)$ is the $Z$ value in the position $x i ; Z(x i+h)$ is the $Z$ value separated by a distance $h$ in the position $x i$. The theoretical models of the empirical semivariograms were adjusted by interaction and visual inspection. The semivariograms used were omnidirectional, considering the isotropies.

In the second phase, the spatial dependency index (SDI) was calculated considering the parameters nugget effect $(\mathrm{C} 0)$ and sill $(\mathrm{C} 0+\mathrm{C} 1)$ of the semivariograms, according to the expression $[C 1 /(C 0+C 1) * 100]$, classifying it as very low (SDI $<20 \%)$, low $(20<\mathrm{SDI}<40 \%)$, moderate $(40 \%$ $<\mathrm{SDI}<60 \%)$, high $(60 \%<\mathrm{SDI}<80 \%)$, and very high
$(80 \%<\mathrm{SDI}<100 \%)($ DALCHIAVON; CARVALHO, 2012).

\section{RESULTS AND DISCUSSION}

The data of soil resistance to penetration (SRP) were close to a normal distribution (Table 2), since the mean and median values were similar in all sugarcane areas, soil layers, and positions studied. According to Cressie (1991), normality is not required for evaluations of spatial dependency when avoiding elongated tails in distribution curves, which can be found in the present work by the number of coefficients of asymmetry close to zero.

The CVs for the 0.0-0.1 and 0.1-0.2 m soil layers in the planting rows, and for the $0.0-0.1 \mathrm{~m}$ soil layer in the interrows in the MAH area were classified as high, indicating a high variation of the data when compared to the other areas and respective soil layers, which presented moderate CVs.

The MAH area showed decreases in CV, as the depth of the analyzed soil layer was increased. According to Cancian (2015), it can be due to the greater effect of the furrower mechanism of the seeders on the soil surface layers, which causes higher disaggregation, in addition to the constant moistening and drying cycles and biological activity that also affect the soil surface layers. The CVs of the $\mathrm{MMH}$ and $\mathrm{MEH}$ areas had not the same decreasing pattern.

The MAH area presented higher absolute values of SRP than the other areas (Table 2). According to Otto et al. (2011), SRPs above $2 \mathrm{MPa}$ limit root growth in most crops, including sugarcane.

The $\mathrm{MEH}$ and $\mathrm{MMH}$ areas presented low SRP in surface layers $(0.0-0.3 \mathrm{~m})$ and increasing SRP in deeper layers. The higher SRP values in the subsurface layers can be explained by the management or cohesion conditions of the soil due to low moisture content in the sampling point.

The MEH and MMH areas presented higher SRP in the planting interrow due to the passing of the harvester wheels, which causes intense soil compression. The MAH area presented higher SRP in the planting row, with mean of $4.06 \mathrm{MPa}$, which was not expected and can be limiting for root growth. 
Table 2. Descriptiv estatistics of data of soil resistance to penetration (SRP; MPa) in areas with manual harvest, mechanized harvest, and manual/mechanized harvest of sugarcane crops grown in a Typic Hapludult.

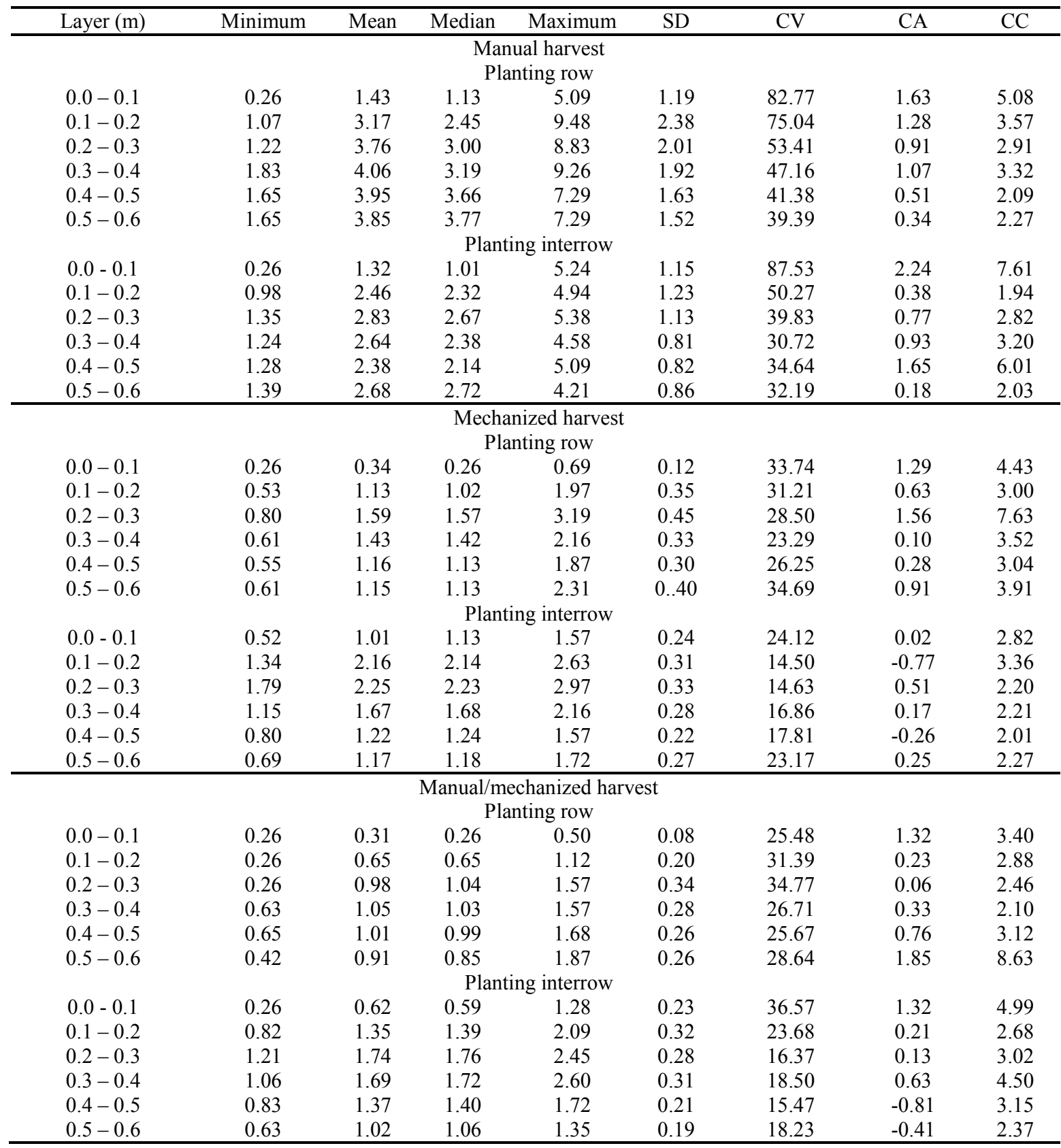

$\mathrm{SD}=$ standard deviation; $\mathrm{CV}=$ coefficient of variation; $\mathrm{CA}=$ coefficient of asymmetry; $\mathrm{CC}=$ coefficient of kurtosis.

The higher SRP in the MAH area is due to the soil moisture in this area, which varied from 0.02 to $0.04 \mathrm{~kg} \mathrm{~kg}^{-1}$ and was lower than that found in the other areas (Table 3). The result is consistent with those of Carvalho Filho et al. (2004), who reported that SRP tends to vary inversely to soil water content. Lima et al. (2013) evaluated soils under different textures and found increases in SRP as the soil moisture was decreased, which is explained by the higher presence of water acting as lubricant of particles, hindering penetrometer rod penetration.

The moisture was distributed uniformly in the soil profile and presented free water percolation, indicating that there were no compacted layers. 
M. C. SOUZA et al.

Table 3. Soil gravimetric moisture in areas with manual harvest, mechanized harvest, and manual/mechanized harvest of sugarcane crops grown in a Typic Hapludult.

\begin{tabular}{|c|c|c|}
\hline \multirow{2}{*}{ Layer (m) } & Planting row & Planting interrow \\
\hline & \multicolumn{2}{|c|}{ Soil gravimetric moisture $\left(\mathrm{kg} \mathrm{kg}^{-1}\right)$} \\
\hline & \multicolumn{2}{|c|}{ Manual harvest } \\
\hline $0.0-0.1$ & 0.02 & 0.02 \\
\hline $0.1-0.2$ & 0.02 & 0.02 \\
\hline $0.2-0.3$ & 0.02 & 0.03 \\
\hline $0.3-0.4$ & 0.03 & 0.04 \\
\hline $0.4-0.5$ & 0.04 & 0.04 \\
\hline $0.5-0.6$ & 0.04 & 0.04 \\
\hline \multicolumn{3}{|c|}{ Mechanized harvest } \\
\hline $0.0-0.1$ & 0.07 & 0.07 \\
\hline $0.1-0.2$ & 0.07 & 0.08 \\
\hline $0.2-0.3$ & 0.09 & 0.09 \\
\hline $0.3-0.4$ & 0.11 & 0.11 \\
\hline $0.4-0.5$ & 0.12 & 0.13 \\
\hline $0.5-0.6$ & 0.13 & 0.14 \\
\hline \multicolumn{3}{|c|}{ Manual/mechanized harvest } \\
\hline $0.0-0.1$ & 0.08 & 0.11 \\
\hline $0.1-0.2$ & 0.08 & 0.10 \\
\hline $0.2-0.3$ & 0.07 & 0.10 \\
\hline $0.3-0.4$ & 0.08 & 0.11 \\
\hline $0.4-0.5$ & 0.08 & 0.10 \\
\hline $0.5-0.6$ & 0.08 & 0.10 \\
\hline
\end{tabular}

The maps shown in Figures 2, 3 and 4 are the kriging of the areas. This interpolated surface presents the spatial distribution of each variable, comparing the SRP in the planting row and in the planting interrow in the different soil layers. It allows the identification of location and coverage of extreme values, degree of homogeneity of the area, and greater gradient directions.

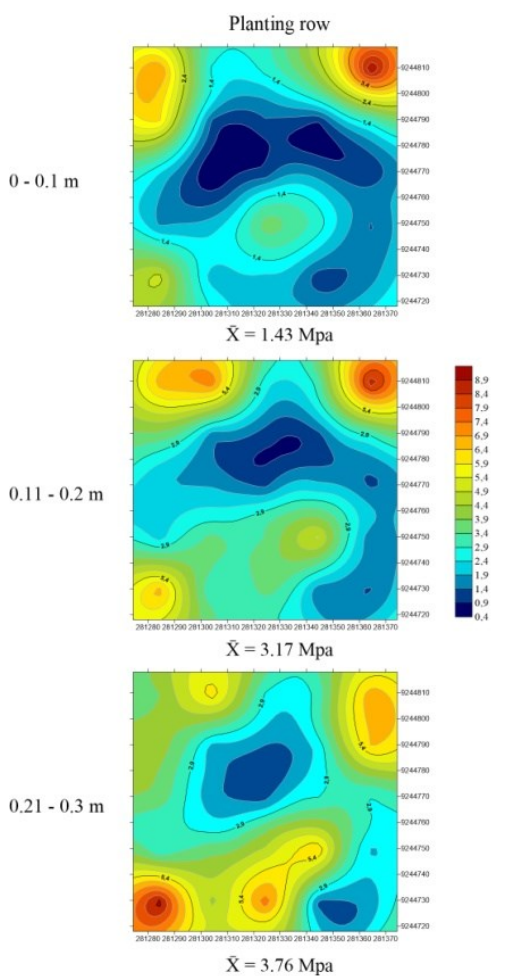

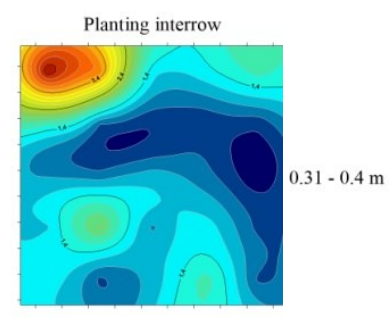

$\overline{\mathrm{X}}=1.32 \mathrm{Mpa}$

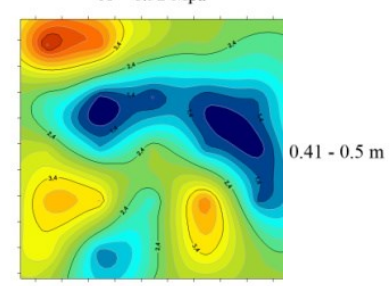

$\overline{\mathrm{X}}=2.46 \mathrm{Mpa}$

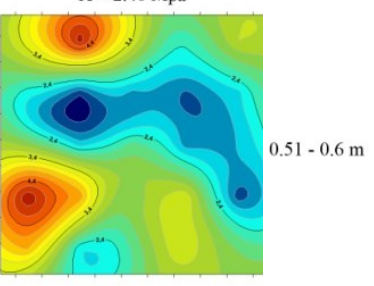

$\overline{\mathrm{X}}=2.83 \mathrm{Mpa}$

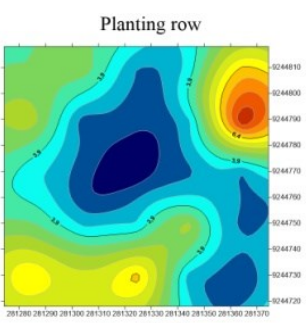

$\overline{\mathrm{X}}=4.06 \mathrm{Mpa}$

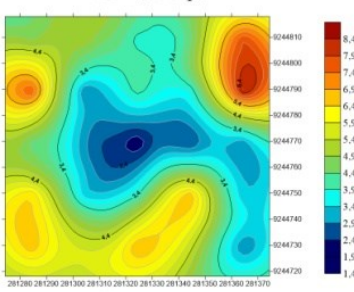

$\overline{\mathrm{X}}=3.95 \mathrm{Mpa}$

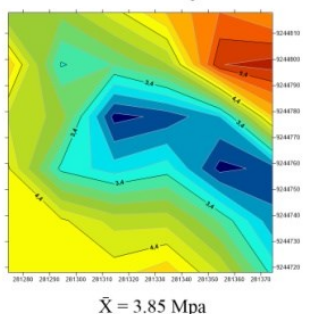

Planting interrow

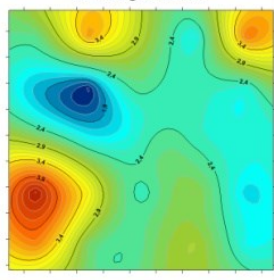

$\overline{\mathrm{X}}=2.64 \mathrm{Mpa}$

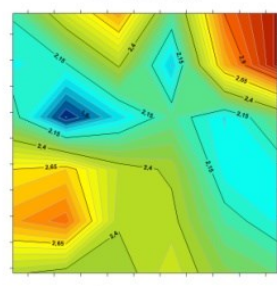

$\overline{\mathrm{X}}=2.38 \mathrm{Mpa}$

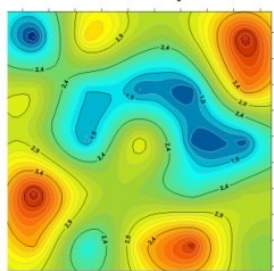

$\overline{\mathrm{X}}=2.68 \mathrm{Mpa}$

Figure 2. Kriging maps for soil resistance to penetration (SRP) comparing data of planting row and planting interrow in different soil layers $(0-0.60 \mathrm{~m})$ in the area with manual harvest $(\mathrm{MAH})$ of sugarcane crops grown in a Typic Hapludult. 


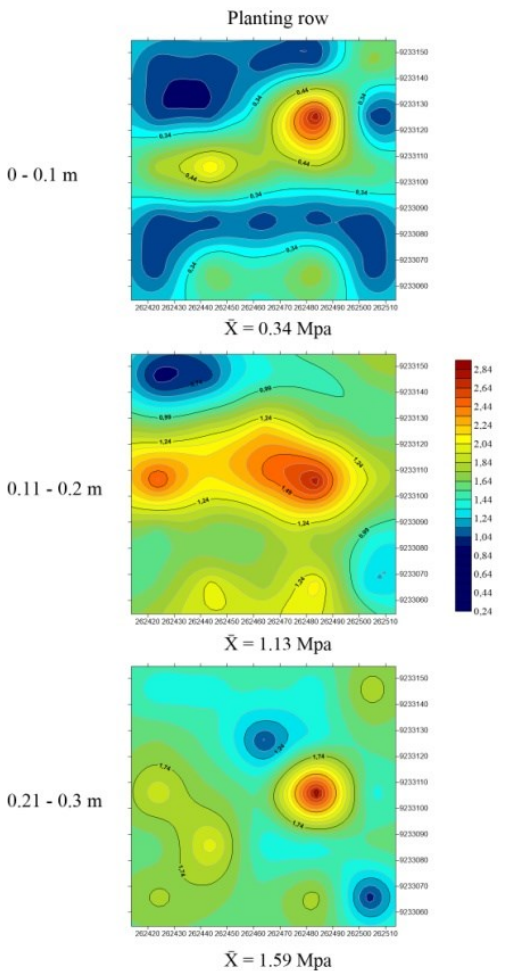

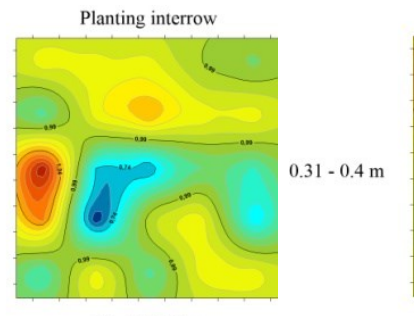

$\overline{\mathrm{X}}=1.01 \mathrm{Mpa}$

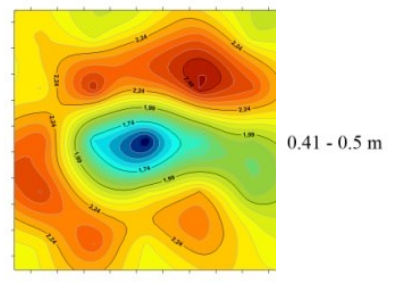

$\overline{\mathrm{X}}=2.16 \mathrm{Mpa}$

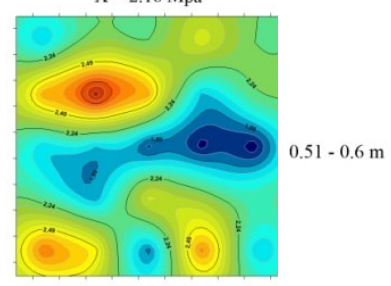

$\overline{\mathrm{X}}=2.25 \mathrm{Mpa}$
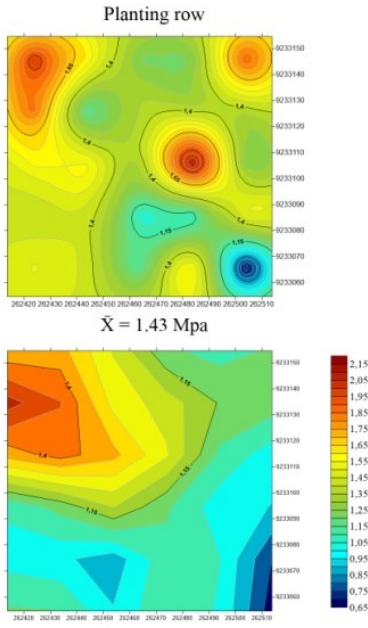

$\overline{\mathrm{X}}=1.16 \mathrm{Mpa}$

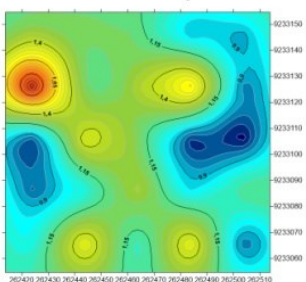

$\overline{\mathrm{X}}=1.15 \mathrm{Mpa}$

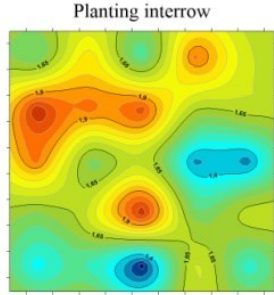

$\overline{\mathrm{X}}=1.67 \mathrm{Mpa}$

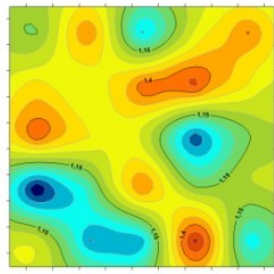

$\overline{\mathrm{X}}=1.22 \mathrm{Mpa}$

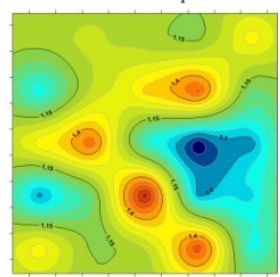

$\overline{\mathrm{X}}=1.17 \mathrm{Mpa}$

Figure 3. Kriging maps for soil resistance to penetration (SRP) comparing data of planting row and planting interrow in different soil layers $(0-0.60 \mathrm{~m})$ in the area with mechanized harvest (MEH) of sugarcane crops grown in a Typic Hapludult.
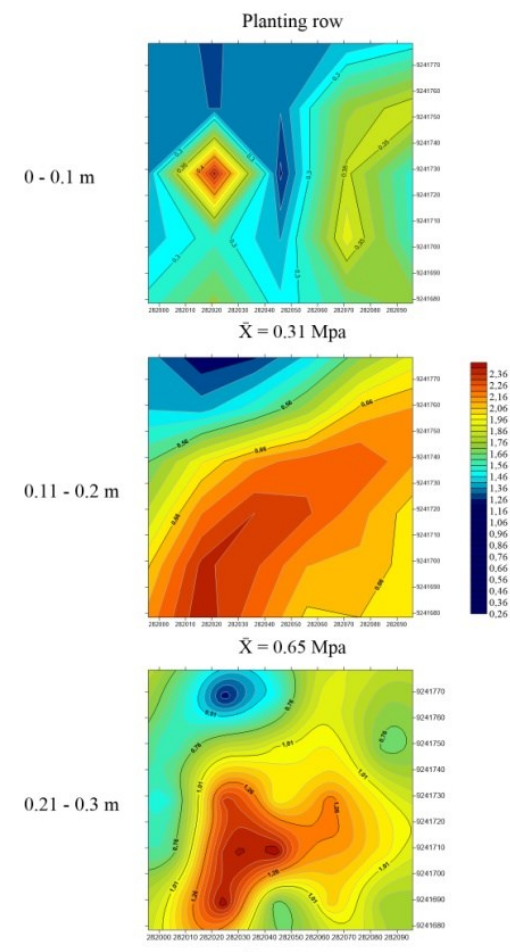

$\overline{\mathrm{X}}=0.98 \mathrm{Mpa}$

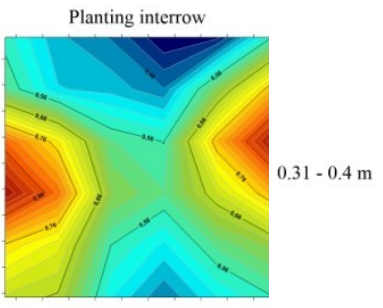

$\overline{\mathrm{X}}=0.62 \mathrm{Mpa}$

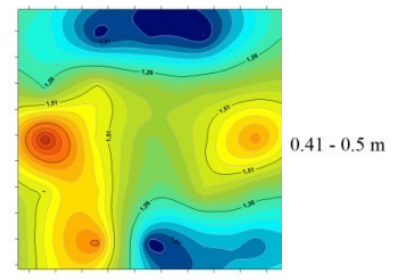

$\overline{\mathrm{X}}=1.35 \mathrm{Mpa}$

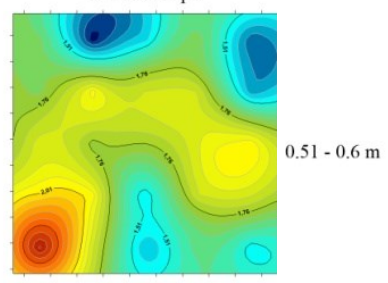

$\bar{X}=1.74 \mathrm{Mpa}$
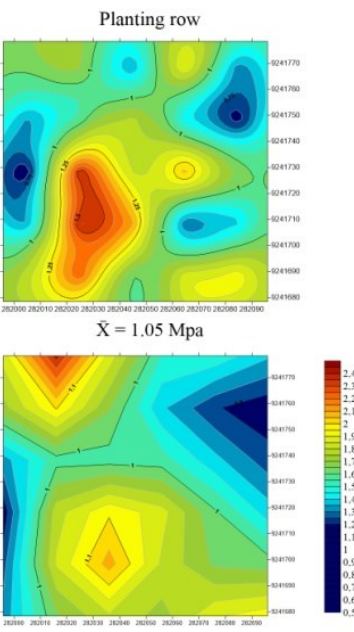

$\overline{\mathrm{X}}=1.01 \mathrm{Mpa}$

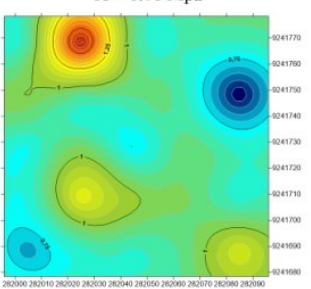

$\overline{\mathrm{X}}=0.91 \mathrm{Mpa}$
Planting interrow

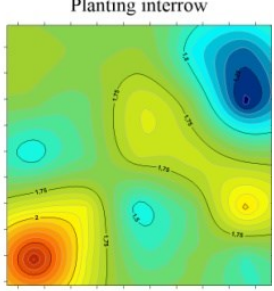

$\overline{\mathrm{X}}=1.69 \mathrm{Mpa}$

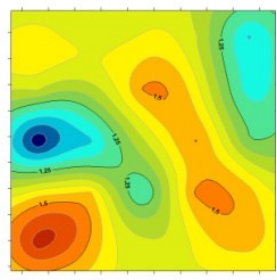

$\overline{\mathrm{X}}=1.37 \mathrm{Mpa}$

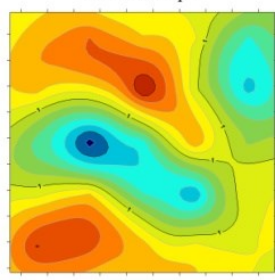

$\overline{\mathrm{X}}=1.02 \mathrm{Mpa}$

Figure 4. Kriging maps for soil resistance to penetration (SRP) comparing data of planting rowand planting interrow in different soil layers $(0-0.60 \mathrm{~m})$ in the area with manual/mechanized harvest $(\mathrm{MMH})$ of sugarcane crops grown in a Typic Hapludult. 
The variables presented, predominantly, very high spatial dependency index (SDI) (Table 4). Only the $0.1-0.3 \mathrm{~m}$ soil layer in the planting row of the $\mathrm{MEH}$ area, and the 0.3-0.5 m layer in the planting interrow of the MMH area presented high SDI; and the $0.1-0.2 \mathrm{~m}$ soil layer in the planting row of the $\mathrm{MMH}$ area presented intermediate SDI. Thus, the semivariogram explained well the spatial variance of the data for $94 \%$ of the variables.

Table 4. Parameters of semivariogram models for soil resistance to penetration (MPa) in areas with manual harvest, mechanized harvest, and manual/mechanized harvest of sugarcane crops grown in a Typic Hapludult.

\begin{tabular}{|c|c|c|c|c|c|}
\hline Layer (m) & $\mathrm{C}_{0}$ & $\mathrm{C}_{0}+\mathrm{C}_{1}$ & Range (m) & Model & SDI (\%) \\
\hline \multicolumn{6}{|c|}{$\begin{array}{l}\text { Manual harvest } \\
\text { Planting row }\end{array}$} \\
\hline $0.0-0.1$ & 0.2 & 1.22 & 43 & Spherical & 84 \\
\hline $0.1-0.2$ & 0.5 & 5.00 & 41 & Spherical & 90 \\
\hline $0.2-0.3$ & 0.4 & 4.00 & 40 & Spherical & 90 \\
\hline $0.3-0.4$ & 0.5 & 3.60 & 41 & Spherical & 86 \\
\hline $0.4-0.5$ & 0.5 & 2.75 & 35 & Spherical & 82 \\
\hline $0.5-0.6$ & 0.5 & 3.21 & 40 & Exponential & 84 \\
\hline \multicolumn{6}{|c|}{ Planting interrow } \\
\hline $0.0-0.1$ & 0.2 & 1.07 & 43 & Spherical & 81 \\
\hline $0.1-0.2$ & 0.2 & 1.53 & 35 & Spherical & 87 \\
\hline $0.2-0.3$ & 0.2 & 1.25 & 38 & Spherical & 84 \\
\hline $0.3-0.4$ & 0.1 & 0.60 & 45 & Spherical & 83 \\
\hline $0.4-0.5$ & 0.1 & 0.60 & 28 & Spherical & 83 \\
\hline $0.5-0.6$ & 0.04 & 0.74 & 31 & Spherical & 95 \\
\hline \multicolumn{6}{|c|}{ Mechanized harvest } \\
\hline \multicolumn{6}{|c|}{ Planting row } \\
\hline $0.0-0.1$ & 0.002 & 0.0155 & 29 & Spherical & 87 \\
\hline $0.1-0.2$ & 0.04 & 0.14 & 46 & Spherical & 71 \\
\hline $0.2-0.3$ & 0.05 & 0.243 & 25 & Spherical & 79 \\
\hline $0.3-0.4$ & 0.01 & 0.102 & 28 & Spherical & 90 \\
\hline $0.4-0.5$ & 0.012 & 0.109 & 30 & Exponential & 89 \\
\hline $0.5-0.6$ & 0.02 & 0.146 & 27 & Spherical & 86 \\
\hline \multicolumn{6}{|c|}{ Planting interrow } \\
\hline $0.0-0.1$ & 0.0105 & 0.0704 & 27 & Spherical & 85 \\
\hline $0.1-0.2$ & 0.02 & 0.133 & 40 & Spherical & 85 \\
\hline $0.2-0.3$ & 0.0158 & 0.1188 & 29 & Spherical & 87 \\
\hline $0.3-0.4$ & 0.01 & 0.079 & 27 & Spherical & 87 \\
\hline $0.4-0.5$ & 0.005 & 0.047 & 27 & Spherical & 89 \\
\hline $0.5-0.6$ & 0.0113 & 0.0883 & 25 & Spherical & 87 \\
\hline \multicolumn{6}{|c|}{ Manual/mechanized harvest } \\
\hline $0.0-0.1$ & - & - & - & PNE & - \\
\hline $0.1-0.2$ & 0.02 & 0.044 & 35 & Exponential & 55 \\
\hline $0.2-0.3$ & 0.003 & 0.114 & 39 & Spherical & 97 \\
\hline $0.3-0.4$ & 0.0056 & 0.0856 & 31 & Spherical & 93 \\
\hline $0.4-0.5$ & - & - & - & PNE & - \\
\hline $0.5-0.6$ & 0.01 & 0.065 & 32 & Spherical & 85 \\
\hline \multicolumn{6}{|c|}{ Planting interrow } \\
\hline $0.0-0.1$ & 0.0045 & 0.0695 & 30 & Exponential & 94 \\
\hline $0.1-0.2$ & 0.01 & 0.115 & 49 & Spherical & 91 \\
\hline $0.2-0.3$ & 0.0033 & 0.0781 & 46 & Spherical & 96 \\
\hline $0.3-0.4$ & 0.02 & 0.095 & 45 & Spherical & 79 \\
\hline $0.4-0.5$ & 0.015 & 0.047 & 40 & Spherical & 68 \\
\hline $0.5-0.6$ & 0.005 & 0.0427 & 39 & Spherical & 88 \\
\hline
\end{tabular}

$\mathrm{C}_{0}=$ nugget effect; $\mathrm{C}_{0}+\mathrm{C}_{1}=$ sill; $\mathrm{SDI}=$ spatial dependency index; $\mathrm{PNE}=$ pure nugget effect. 
The range values within the same area and position were similar in the whole soil profile; however, considering the absolute values of the areas studied, they were lower in the MEH area, with mean of $30 \mathrm{~m}$ for the planting row and $29 \mathrm{~m}$ for the planting interrow.

These ranges were lower than those reported by Mion et al. (2012) for SRP in a Typic Hapludult of sandy texture under pastures (Bachiaria decumbens and Cynodon sp.) in the state of Ceará, Brazil; they found mean of $310.9 \mathrm{~m}$ in a sampling grid of $30 \times 30 \mathrm{~m}$. Moreover, Coelho et al. (2012) evaluated SRP in a Typic Hapludert of loamy texture grown with mango and found ranges above $21.6 \mathrm{~m}$ in a sampling grid of $10 \times 10 \mathrm{~m}$.

The range is affected by the soil type and use, and management applied for its use. According to Coelho et al. (2012), the quantity and distribution of soil samples in the field can also affect the range.

\section{CONCLUSIONS}

The soil resistance to penetration presented spatial dependency in all sugarcane areas studied, except for the manual/mechanized harvest area in the $0-0.1 \mathrm{~m}$ and $0.4-0.5 \mathrm{~m}$ soil layers in the planting rows, which presented pure nugget effect.

The soil moisture was uniform throughout the soil profile, indicating that there were no compacted layers.

The soil resistance to penetration found showed no occurrence of compacted zones that are limiting for root growth.

\section{REFERENCES}

BRAUNACK, M. V. et al. Effect of harvest traffic position on soil conditions and sugarcane (Saccharum officinarum) response to environmental conditions in Queensland, Australia. Soil and Tillage Research, 89: 103-121, 2006.

CANCIAN, L. C. Variabilidade espacial da resistência a penetração, granulometria e umidade do solo. 2015. 59 f. Dissertação (Mestrado em Agronomia: Área de concentração em Ciência do Solo), Universidade Federal de Santa Maria, FredericoWestphalen, 2015.

CARVAlHO FILHO, A. et al. Compactação do solo em cafeicultura irrigada. Uberaba, $\mathrm{MG}$ : UNIUBE, 2004. 44 p.

CASTRO, A. N. C. et al. Avaliação de atributos físicos do solo em diferentes anos de cultivo de canade-açúcar. Revista Agrarian, 6: 415-422. 2013.
CAVALIERI, K. M. V. et al. Qualidade física de três solos sob colheita mecanizada de cana-de-açúcar. Revista Brasileira de Ciência do Solo, 35: 15411550, 2011.

COELHO, D. S. et al. Variabilidade espacial da resistência mecânica à penetração em Vertissolo cultivado com manga no perímetro irrigado de Mandacaru, Juazeiro, Bahia, Brasil. Revista Brasileira de Ciência do Solo, 36: 755-764, 2012.

COMPANHIA NACIONAL DE ABASTECIMENTO - CONAB. Acompanhamento da Safra Brasileira de Cana-de-Açúcar: quarto levantamento. safra 2017/2018. Brasília: CONAB. 2017. 62 p. Disponível em: <http:// www.conab.gov.br/OlalaCMS/uploads/

arquivos/17_04_20_14_04_31_boletim_cana_portug ues_-_10_lev_-_17-18.pdf $>$. A Acesso em: 30 maio $201 \overline{7}$.

CRESSIE, N. A. C. Statistics for spatial data. New York, NY: John Wiley, 1991. 900 p.

DALCHIAVON, F. C; CARVALHO, M. P. Correlação linear e espacial dos componentes de produção e produtividade da soja. Semina: Ciências Agrárias, 33: 541-552, 2012.

FAO. FAOSTATS. Agricultura - Divisão de Estatísticas da FAO. 2014. Disponível em: $<\mathrm{http}: / /$ faostat.fao.org/site/339/default.aspx $>$. Acesso em: 20 abr. 2017.

GEE, G. W.; BAUDER, J. W. Particle-size analysis. In: KLUTE, A. Methods of soil analysis. American Society of Agronomy, 1: 383-411, 1986.

INSTITUTO BRASILEIRO DE GEOGRAFIA E ESTATÍSTICA - IBGE. Malha Municipal: Municípios da Paraíba. 2013. Disponível em: $<$ http://downloads.ibge.gov.br/

downloads_geociencias.htm>. Acesso em: 30 jul. 2017.

LIMA, R. P. et al. Compactação do solo de diferentes classes texturais em áreas de produção de cana-de-açúcar. Revista Ceres, 60: 16-20, 2013.

MION, R. L. et al. Variabilidade espacial da porosidade total, umidade e resistência do solo à penetração de um Argissolo Amarelo. Semina: Ciência Agrárias, 33: 2057-2066, 2012.

OLIVEIRA, I. A. et al. Variabilidade espacial de atributos físicos em um Cambissolo Háplico, sob diferentes usos na região Sul do Amazonas. Revista Brasileira de Ciência do Solo, 37: 1103-1112, 2013. 
OTTO, R. et al. High soil penetration resistance reduces sugarcane root system development. Soil and Tillage Research, 117: 201-210, 2011.

SANTOS, H. G. et al. Sistema Brasileiro de Classificação de Solos. 5. ed. Brasília, DF: Embrapa. 2018. 356 p.

SILVA, A. J. N.; CABEDA, M. S. V. Compactação e compressibilidade do solo sob sistemas de manejo e níveis de umidade. Revista Brasileira de Ciência do Solo, 30: 921-930, 2006.

SOUZA, Z. M. et al. Spatial variability of the physical and mineralogical properties of the soil from the areas with variation in landscape shapes. Brazilian Archives of Biology and Technology, 52: 305-316, 2009.

TEIXEIRA, P. C. et al. Manual de métodos de análise de solos. 3.ed. Rio de Janeiro, RJ: Embrapa Solos. 2017. 573 p.

WARRICK, A. W.; NIELSEN, D. R. Spatial variability of soil physical properties in the field. In: HILLEL, D. (Ed.). Applications of Soil Physics. New York, NY: Academic Press, 1980. v. 1, cap. 2, p. 319-344. 